\title{
Editorial
}

\section{The legitimacy of human rights courts in environmental disputes}

Recent years have seen an increasing recognition of the strong interconnection between human rights and environmental protection. A growing number of disputes adjudicated in regional human rights courts now deal with environmental aspects of human rights claims and, consequently, a growing body of human rights-related jurisprudence is emerging with direct legal relevance for environmental protection. While this is a welcome, necessary and fascinating development, it raises a number of questions concerning the legitimacy of human rights courts in dealing with environmental issues, most prominent among them whether human rights courts are even the right venue for environmental disputes.

On 8 and 9 September 2014, PluriCourts (the Centre of Excellence at the Faculty of Law of the University of Oslo) invited renowned scholars, young academics and judges to exchange views on the legitimacy of adjudication of environmental cases in human rights tribunals. Among the participants were Helen Keller (Judge, European Court of Human Rights), Margarette May Macaulay (former Judge, Inter-American Court of Human Rights), Justice Hansine Donli (former President ECOWAS), Professor Dinah Shelton (George Washington University) and Professor Alan Boyle (University of Edinburgh). The articles in this edition of the Journal of Human Rights and the Environment are predominantly drawn from papers presented at the PluriCourts conference and offer contributions to the ongoing engagement with the theme at its heart.

Established in 2013, PluriCourts is a Centre dedicated to the study of the legitimate role/s of the judiciary in the global order. PluriCourts examines such questions as the legitimacy of international courts, from legal, political science and philosophical perspectives, as well as researching and reflecting upon the functioning of International Courts, and their effects. To address its research agenda, PluriCourts focuses on five sectors of international law, namely Human Rights, Trade, Criminal, Investment and Environmental Law.

\section{ENVIRONMENTAL SECTOR}

When it comes to international environmental law the global juridical order places the subject in a very particular position: there are no special international environmental courts exercising jurisdiction over the (by now) hundreds - if not thousands - of multilateral treaties that deal with environmental protection. What exist are, on the one hand, so-called non-compliance or review mechanisms and procedures with judicial features under multilateral environmental treaty regimes. These mechanisms deal with issues of non-compliance through facilitative approaches by providing transparency, financial and technological assistance and capacity-building rather than sanctions. Examples include the Compliance Committees under the Kyoto Protocol and the Aarhus Convention on Access to Justice in Environmental Matters. 
On the other hand, a large amount of jurisprudence touching upon environmental matters now emanates not from specialized environmental courts but from issue-specific judicial bodies, such as the Dispute Settlement System of the WTO, international investment arbitration tribunals or - the focus of this edition - human rights courts, i.e. regional courts such as the European Court of Human Rights or the Inter-American Court of Human Rights, as well as human rights treaty bodies.

In the absence of an international environmental tribunal, some argue that human rights courts can offer a value-added approach complementing national legislation and providing for a unified forum when addressing global problems. Human rights courts, it is argued, can also help to promote the rule of law in ensuring the accountability of governments with regards to their environmental obligations.

Such advantages, in combination with the absence of an international tribunal with special jurisdiction for environment-related legal disputes, mean that human rights courts are confronted with a growing number of cases with environmental aspects, are interpreting human rights instruments to accommodate environmental issues and are developing an extensive jurisprudence on environmental rights. Indeed, these bodies currently offer the only international adjudication procedures for individuals to challenge governmental action or non-action in relation to environmental matters. In other words, human rights courts and other quasi-judicial human rights bodies present opportunities that otherwise do not exist for pursuing environmental claims on the international plane.

\section{HUMAN RIGHTS AND THE ENVIRONMENT}

In most cases, safeguarding human rights and preserving the environment are complementary objectives. The Independent Expert on the issue of human rights obligations relating to the enjoyment of a safe, clean, healthy and sustainable environment, John Knox, noted in his first report that 'environmental degradation can and does adversely affect the enjoyment of a broad range of human rights' ${ }^{1}$ Climate change, desertification, mining activities, industrial air and water pollution, large-scale oil development, improper disposal of toxic wastes, exposure to harmful chemicals or to radiation and the improper use of pesticides - among other developments and activities - can pose threats to the right to life, to the highest attainable standard of physical and mental health, to an adequate standard of living, to the right to food and to the right to respect for family life - and other human rights.

Certain groups may even be particularly vulnerable to environmental threats. The rights of children, for example, can be particularly affected by environmental degradation. The Convention on the Rights of the Child states that environmental pollution poses 'dangers and risks' to nutritious foods and clean drinking water, ${ }^{2}$ and environmental hazards are often barriers to the realization of children's rights to health and to other rights. Additionally, indigenous peoples because of their close relationship with their lands, with nature and with natural resources, can be uniquely vulnerable to

1. Report of the Independent Expert on the issue of human rights obligations relating to the enjoyment of a safe, clean, healthy and sustainable environment, John H. Knox, A/HRC/22/43, 24 December 2012.

2. Art 24 para 2(c) UN General Assembly, Convention on the Rights of the Child, 20 November 1989, United Nations, Treaty Series, vol. 1577, p. 3, available at <http://www. refworld.org/docid/3ae6b38f0.html> accessed 13 May 2015. 
environmental degradation. Activities related to extractive industries, in particular, can generate effects that often infringe upon indigenous peoples' rights - such as the rights to life, health, property, culture, etc.

Despite the growing contemporary awareness of the intimacy between environmental quality and fundamental human rights and interests, it remains the case that few international human rights agreements recognize the close interconnection between human rights and the environment explicitly. And even fewer recognize a human right to a healthy environment. In fact, environmental rights have been proclaimed in only two regional human rights treaties: The African Charter of Human and Peoples' Rights (which provides that 'all peoples shall have the right to a general satisfactory environment favourable to their development') $)^{3}$ and the Additional Protocol to the American Convention on Human Rights (which states that 'everyone shall have the right to live in a healthy environment and to have access to basic public services'). ${ }^{4}$

Other human rights treaties contain no such explicit guarantees. The European Convention on Human Rights (ECHR), for example, does not provide for a right to a healthy environment and is thus dependent on the interpretation of other, explicitly enumerated, human rights, such as the right to private and family life, to include or to extend to environmental matters. This is an interpretive strategy, as noted above, now widely recognizable in the practice of human rights courts, which have been increasingly active in applying existing general human rights norms to environmental issues and environmentally-sensitive interpretative strategies to existing human rights and jurisprudence. As a result, these human rights courts and bodies have begun to develop an important body of environment-related human rights jurisprudence in relation to procedural rights as well as to substantive rights. Taken together, such developments provide strong evidence of converging trends towards greater uniformity and certainty concerning human rights obligations relating to the environment.

\section{AIM OF THIS EDITION}

Given this developing jurisprudential strategy and the amount of case law it has already produced, we consider this an opportune moment to step back and reflect on this dynamic evolution in human rights adjudication. This edition of the Journal of Human Rights and the Environment thus focuses on the question of the legitimacy of using human rights tribunals to resolve disputes of an environmental nature, as an important threshold matter.

Such an inquiry raises issues such as: Are human rights courts prepared for such cases (that are often value-laden and heavily science-based) and how? Do human rights courts have the expertise and institutional capacity to deal with environmental matters? Are existing rules of standing, jurisdiction, procedure, evidence, causality, etc., adequate when confronted with the complexities of environmental issues? What is the role of international (and national) environmental law before human rights courts and tribunals? Are human rights courts effective 'instruments' for environmental protection? Are human

3. Article 24, Organization of African Unity (OAU), African Charter on Human and Peoples' Rights ('Banjul Charter'), 27 June 1981, CAB/LEG/67/3 rev. 5, 21 I.L.M. 58 (1982), available at <http://www.refworld.org/docid/3ae6b3630.html> accessed 13 May 2015.

4. Article 11, Organization of American States, Additional Protocol to the American Convention on Human Rights in the Area of Economic, Social, and Cultural Rights ('Protocol of San Salvador'), 17 November 1988, OAS Doc. OAS/Ser.L/V/I.4 rev. 13. 
rights courts more suitable for the protection of some environmental problems than others, for example for local rather than global challenges? What are the legitimate roles, functions and effects of human rights courts in cases concerning environmental matters?

On a more general level, there remain legitimate concerns as to the appropriateness of transforming issues of environmental protection and the intrinsic value of nature into human rights questions, especially given the inherently anthropocentric nature of human rights. There are also legitimate concerns about reducing the 'collectiveness' of public interest in environmental matters to individual (human) rights claims. Human rights law, as is well-known, is fundamentally concerned with the protection of individual well-being, while environmental law is primarily orientated towards the protection of collective well-being. Historically and systemically, human rights have emerged from a political liberalism favouring the protection of individual freedom over the protection of groups or of entire populations. This 'reduced concept of freedom' means that human rights protect individualized legal positions in relative isolation from social and ecological conditions. Human rights archetypally protect citizens against the state. In other words they protect humans from each other: they contain no provision to stop humans from exploiting non-humans or from fundamentally changing their conditions of life. Within this paradigm, environmental degradation is only relevant in so far as it causes a direct and severe violation of individual rights.

This limited focus also links to analogous conceptual limitations placed upon procedural aspects of standing and access to human rights courts. The European Court of Human Rights (ECtHR), for example, defines as rights-holders only those 'affected' by an activity detrimental to the environment. The ECtHR also takes the view that an environmental impact must amount to an actual interference with an individual right and attain a certain minimum level in order to engage the right. Additionally, in many cases of environmental degradation, while there is an entirely foreseeable likely interest in preventing environmental harm from occurring in the first place rather than seeking compensation or relief after the event, human rights systems tend to take a reactive approach to environmental harm. This is rather different from the purpose of many international environmental treaties, which aim at proactively preventing environmental harm.

Related to these tensions and limitations is the problem of ratio personae of certain human rights norms. In many cases, especially those decided by the ECtHR, a direct link between the environmentally destructive activity and the applicant's right is required. Such a narrow approach effectively seals off access to courts for individuals (or NGOs) that have a genuine interest in the environment and whose aim is to protect environmental assets - whether, for example, they be wetlands, forests, ecosystems or species - against destruction by states or third parties. In Kyrtatos v Greece, ${ }^{5}$ for example, the applicants complained that tourist development on the beautiful Greek island where they lived had caused the destruction of forests and a particularly rich wetland and that this had affected their right to private life under Article 8 ECHR. The applicants pointed out that 'the area had lost all of its scenic beauty and had changed profoundly in character from a natural habitat for wildlife to a tourist development. Part of the wetland had been reclaimed so as to create, in addition to the buildings, a car park and a road'. Yet, the court found that:

even assuming that the environment has been severely damaged by the urban development of the area, the applicants have not brought forward any convincing arguments showing that

\section{ECHR, Judgment of 22 May 2003.}


the alleged damage to the birds and other protected species living in the swamp was of such a nature as to directly affect their own rights under Article $8 \S 1$ of the Convention ... [explicitly stating that] [n]either Article 8 nor any of the other Articles of the Convention are specifically designed to provide general protection of the environment as such; to that effect, other international instruments and domestic legislation are more pertinent in dealing with this particular aspect.

A further legitimacy concern relates to the effectiveness of human rights courts in remedying the violation of a particular human right by environmental degradation. Remedies afforded by human rights courts may cover the human rights injuries (to health or private life for example) suffered, but they seldom contribute to remedying the source of the violation - in other words they do not generally play a part in ensuring environmental protection. Only very seldom have human rights courts ordered specific action to be taken to remedy environmental harm. Prominent examples of such specific action include a number of judgments of the Inter-American Court of Human Rights that have addressed environmental harm amounting to a violation of collective property rights of indigenous peoples, as well as a judgment of The Court of Justice of the Economic Community of West African States (ECOWAS) in which the Federal Republic of Nigeria was ordered to: 'Take all effective measures to ensure restoration of the environment of the Niger Delta by oil spills from Shell and other companies and to take all effective measures to prevent the occurrence of damage to the environment' ${ }^{6}$

The fact is that there is little jurisprudence on the environmental duties of states corresponding to or complementing human rights. There is - as yet - no theory on how environmental rights may be related to environmental duties - an issue widely overlooked in the environmental rights debate thus far.

Other legitimacy concerns relate to questions of evidence, causality and how to deal with risk and scientific uncertainty. What role can and should the precautionary principle play in human rights proceedings, especially in cases where there is inconclusive or contradictory evidence provided by experts from 'each side'?

The aim of the PluriCourts Conference and of this edition of the Journal is accordingly to question whether there are legitimacy challenges when human rights courts deal with disputes involving environmental matters, to explore a range of answers to the question, and to reflect upon the implications of these answers for environmental protection.

Shelton's article sets the scene for the edition as a whole. She makes the case for human rights tribunals as legitimate and necessary venues for consideration of human rights violations linked to environmental conditions, especially in the absence of environmental monitoring and enforcement bodies in international law. Her contention is that human rights tribunals do not enforce international environmental standards per se, but that human rights cases based on environmental harm are appropriately coming before human rights tribunals because, first, they involve human rights violations over which such tribunals have jurisdiction: in the absence of specifically recognized environmental rights, UN treaty bodies and regional human rights tribunals appropriately consider environmental harm when such harm violates the guaranteed rights in the treaties over which

6. Socio-Econ. Rights \& Accountability Project (SERAP) v Nigeria, Judgment No. ECW/ CCJ/JUD/18/12, ECOWAS (14 Dec 2012), available at <http://www.courtecowas.org/ site2012/pdf_files/decisions/judgements/2012/SERAP_V_FEDERAL_REPUBLIC_OF_ NIGERIA.pdf>. 
they have jurisdiction or when states fail to enforce environmental rights or standards incorporated into their national constitutions and laws.

Secondly, Shelton argues, human rights tribunals appropriately and legitimately interpret and apply the human rights instruments over which they have jurisdiction, taking into account recent developments in International Human Rights Law and 'other relevant rules of international law' including instruments such as the ILO Convention No 169 concerning Indigenous and Tribal Peoples in Independent Countries, which recognizes the close connection between the environment and a wide range of human rights. And, thirdly, Shelton contends, human rights tribunals legitimately determine the quality of environmental standards required to comply with the substantive guarantees contained in the instruments over which they have jurisdiction. Thus, for example, the ECtHR has held that if environmental pollution affects the wellbeing of individuals to such an extent that it has an impact on their enjoyment of home, private and family life, this will constitute a violation of Article 8 of the ECHR. Such determinations do not involve tribunals in protecting landscapes, habitats, endangered species or other aspects of nature in themselves, but are legitimate determinations of claims concerning violations of rights protected under relevant human rights treaties. While acknowledging that human rights courts face difficulties in cases in which environmental harm is raised - issues which are often labelled as issues of policy or as 'science-based' and therefore falling outside of the expertise of courts - Shelton disputes the notion that environmental cases are inherently more difficult for courts to deal with than any other cases which raise broadly worded standards or highly technical matters. Courts often deal with such matters outside the environmental context and are well equipped to establish the proper limits of environmental decision making and to set standards to ensure protection of the natural environment, upon which life and well-being depends, she contends.

Grant engages with two of the most fundamental obstacles to using human rights adjudication to protect the environment, namely the individualistic approach to rights and, relatedly, the disconnection between rights that often characterizes human rights adjudication. Her article investigates the extent to which the problems of individualism and disconnection are manifested in the jurisprudence of the institutions of the three regional human rights regimes, the ECtHR, the Inter-American Commission and Court of Human Rights (IACommHR and IACtHR) and the African Commission and Court of Human and Peoples' Rights (ACommHPR and ACtHPR) in cases involving environmental claims. She argues that while the ECtHR in particular has a tendency to individualize and disconnect rights, and that this plays a role in limiting environmental protection via human rights in the European system, at the same time, the ECtHR has extended environmental protection under Article 8, by requiring compliance with procedural requirements prior to the making of decisions in relation to the environment which could affect Article 8 rights as well as in recognizing that rights such as the right to property can be legitimately limited in order to secure environmental protection. Moreover, the jurisprudence of both the ACommHPR and the IACommHR and IACtHR provides evidence of a much greater appreciation of the impact of environmental degradation on the rights of whole communities and of the interconnection between the environment and a range of different human rights. Such cases demonstrate that individualism and disconnection are not inherent features of human rights adjudication and that there is significant scope for human rights courts to develop approaches to adjudication in cases involving environmental claims which recognize the importance of the environment to whole communities and the intimate connection between the environment and a wide range of human rights. 
Fisher and Lundberg explore the legitimacy of international human rights institutions from the perspective of ecological claims of indigenous peoples within the Inter-American Human Rights system. They contend that the global ecological crisis challenges not only the legitimacy of human rights institutions, particularly related to their effectiveness in protecting rights in the face of unprecedented anthropogenic environmental degradation, but also the legitimacy of human rights as a normative project. They argue that the dominant human rights tradition is deeply anthropocentric and closely associated with 'increasingly-globalized modernist politico-legal market-state institutions that drive ecological crises'. Endorsing an alternative democratic human rights tradition, which recognizes that human social systems, including human rights, cannot be separated from their material surroundings and are 'inextricably interlinked and embedded within complex, autopoetic and co-evolving non-human systems', Fisher and Lundberg argue that human rights within this conception must become tools for protecting the common resources and supportive systems on which rights depend and for contesting the processes that drive socio-ecological crises. The legitimacy of human rights and human rights institutions, they argue, depends on the extent to which human rights fulfil this role. The authors suggest that in the context of ecologically-related claims of indigenous peoples, the legitimacy of human rights tribunals depends on their ability to play a context-sensitive role in rights realization, taking into account the unique social, cultural and spiritual relationship of indigenous groups to their environment. Using Westra's three models of indigenous ecologically related human rights claims in order to evaluate the role of the IACommHR and IACtHR, Fisher and Lundberg conclude that while the Inter-American institutions offer the most extensive protection of indigenous rights available globally, including specialized protection of indigenous property rights and an express recognition of the need to provide protection for ecological indigenous rights, that nonetheless the protection provided is too heavily dependent on an approach which prioritizes property rights and that a broader ecological reading of all rights is necessary in order to secure the normative legitimacy of human rights and human rights institutions.

Townsend places the spotlight on human dignity, arguing that unlike the post-war era, when the primary threat to human dignity emanated from oppressive states, current threats to human dignity arise from environmental challenges such as climate change and resource depletion. Townsend's article therefore considers what an appropriate response to environmental threats to human dignity might be, focusing on the role of both regional human rights courts and on selected domestic Constitutional Courts. She contends that even in the absence of explicit mention of human dignity or acknowledgement of its foundational role in many human rights regimes, courts recognize and protect human dignity in practice in order to give meaning to rights, extend the application of rights and resolve conflicts between rights. In the absence of explicit recognition of environmental rights in many human rights regimes, Townsend argues, consideration of the implications for human dignity of rights violations in cases involving environmental damage or destruction provides an opportunity for courts to broaden protection of the environment via human rights law. One of the most significant barriers to environmental litigation lies in the lack of recognition on the part of human rights courts of the harm caused by environmental destruction or, in many cases, the seriousness of the harm, harm being mostly confined to damage to health, to life or to property. Focusing on harm caused to human dignity would allow courts to consider the impact of damage to the environment on personality, identity, well-being and more broadly, a 'dignified existence', in addition to impacts on health, life or property, thus significantly extending the reach of rights protection in environmental cases. A dignity approach would also allow 
courts to recognize a broader range of rights-holders, opening the way for the recognition of an obligation to protect the environment for future generations, either through direct recognition of the rights of future generations or through recognition that respecting our own dignity demands that we do not cause suffering to those who come after us. In spite of the potential for reliance on human dignity to lead to environmentally unsustainable demands for access to resources, Townsend concludes that a dignity approach demands recognition of the complexities of environmental cases and has the potential to compel courts to consider hard questions concerning competing claims to resource allocation and environmental constraints, rather than avoiding consideration of environmental questions by resorting to procedural solutions or to the acceptance of the status quo without further examination.

The contributions in this edition all recognize the intimate connection between protecting the rights of humans and securing the environment upon which humans depend, not only for their physical existence but for their social, cultural and spiritual flourishing - not to mention their economic prosperity. Each article engages in a different way with the problems and tensions in raising and adjudicating environmental claims in human rights tribunals, challenging us to re-evaluate existing approaches to human rights and the environment and to forge a new conception of human rights reflecting the indivisibility of human rights and the environment, increasingly manifested in the principles and processes implemented by human rights tribunals.

Christina Voigt (Guest Editor)

Professor, University of Oslo, Department of Public and International Law Coordinator, PluriCourts (Environment)

Evadne Grant (JHRE Editor and Guest Editor of this edition) Associate Head of Department of Law, University of the West of England Coordinator, Global Network for the Study of Human Rights and the Environment

(GNHRE) 